\title{
Induction of Nematode-Trapping Organs in the Predacious Fungus Arthrobotrys oligospora (Hyphomycetales) by Infective Larvae of Ostertagia ostertagi (Trichostrongylidae)
}

\author{
By Jørn Grønvold \\ Institute of Hygiene and Microbılogy, \\ Royal Veterinary and Agricultural Unıversity, Denmark.
}

\begin{abstract}
Grenvold, J.: Induction of nematode-trapping organs in the predacious fungus $A r$ throbotrys oligospora (Hyphomycetales) by infective larvae of Ostertagla ostertagl (Trichostrongylidae). Acta vet. scand. 1989, 30, 77-87. - Laboratory experıments were designed to study the influence of temperature, concentrations of nematodes, oxygen tension, light, and nutrient levels, on the induction of nematode-trapping hyphal nets in the predacious fungus Arthrobotrys oligospora When induced by infective Ostertagia ostertag larvae, a maxımum number of nets was produced at $20^{\circ} \mathrm{C}$, at which temperature nets in surplus were produced at larval concentrations up to 1,000 larvae per $\mathrm{cm}^{2}$. A oligospora did not produce nets in an anaerobic atmosphere containing $21 \% \mathrm{CO}_{2}(\mathrm{v} / \mathrm{v})$, and net induction was suppressed to a certain degree by exposure to light. The composition of the medium had an important influence on the saprophytic growth and the net-forming capability of $A$ oligospora as a maximum number of nets was induced at a relatively low concentration of corn meal supporting the relatively sparse mycelium. It was shown that a proportion of trapping nets in A. oligospora maintained their trapping potential for more than 7 weeks when the temperature was below $25^{\circ} \mathrm{C}$. Induction of nematodetrapping organs in A oligospora is discussed in relation to control of infective nematode parasite larvae in cow pats.
\end{abstract}

nematodes; cattle parasites.

\section{Introduction}

The predacious fungus Arthrobotrys oligospora is able to trap migrating nematodes in three-dimensional adhesive nets raised above the surface of the medium. Net formation starts by lateral branch growing out from the vegetative hyphae. This branch curls back and anastomoses with the parent or adjecent hyphae. From this primary loop other loops may be formed by hyphal anastomoses, and eventually a three-dimensional network is created (Fig. 1).

In A. oligospora trapping nets are formed only if the fungus is stimulated (induced) by factors of physio-chemical (e.g. electrical potentials or peptides) or biological (e.g. nematodes and several other soil animals) nature Pramer \& Stoll (1959) were able to induce 


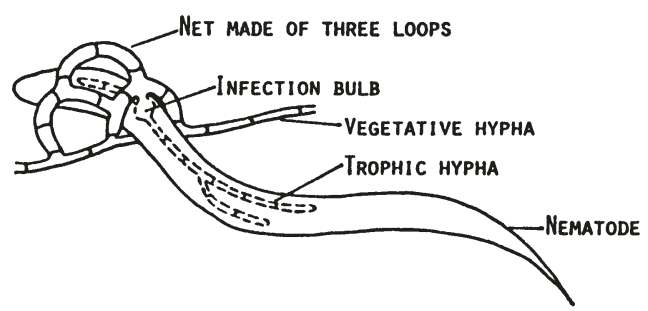

Figure 1. Schematic drawing of a nematode trapped by Arthrobotrys oligospora in a three-dimensional adhesive net made of 3 loops. Only the nets are sticky in A. oligospora. At the point of contact the fungus penetrate the cuticle. Inside the nematode an infection bulb is formed from which trophic hyphae grow out within the nematode and absorb its contents.

trap formation in predacious fungi by a substance isolated from nematodes. They called the substance nemin. Detailed investigations on peptide- and nematode-induced net formation in A. oligospora have been performed by Nordbring-Hertz (1973, 1977).

It was evident that the dipeptide phenylalanyl-valine $(0.1 \mathrm{mg}$ per $\mathrm{ml}$ medium) was effective in inducing nets in A. oligospora if the fungus was grown on a mineral salt medium of low nutrient value, supplied with thiamin and biotin (Nordbring-Hertz 1973). On nutrient-rich media, net induction was depressed. Other peptides, especially valyl peptides, also gave some activity, but the presence of non-polar and aromatic amino acids in the peptides seems important for net induction (Nordbring-Hertz 1973, Nordbring-Hertz \& Brinck 1974). Most amino acids did not induce nets in A. oligospora (Nordbring-Hertz 1973).

The breakdown of proteins or peptides in the environment, or exudations of proteinaceous material from soil animals, may be important in starting the process of net formation. Nematodes excrete $\mathrm{CO}_{2}$, ammonia, acetic acid, and propionic acid, but only ammonia showed a certain effect on net formation in A. oligospora (Nordbring-Hertz \& Odham 1980). Nematodes also excrete small peptides capable of inducing nets in $\mathrm{A}$. oligospora (Nordbring-Hertz 1977), but it is most likely that nematodes are capable of inducing nets in some way other than through peptides.

Living nematodes induce traps in A. oligospora more rapidly than peptides and extracts from nematodes (Nordbring-Hertz 1977). On low-nutrient media, net formation induced by the free-living soil nematode Panagrellus redivivus started within $2 \mathrm{~h}$ and a maximum of nets was reached after $4 \mathrm{~h}$, the rapid response indicating an effect by direct contact between vegetative hyphae and nematodes. It is possible that electrical potentials arising from muscle concentrations of moving nematodes are capable of inducing net formation, as it has been shown that applied electrical potentials are able to bring about trap induction in A. oligospora (Nordbring-Hertz 1977). This agrees with the observation that fast-moving nematodes induce traps most rapidly (Jansson \& NordbringHertz 1980). Perhaps nematodes in this way affect the surface potential of the vegetative hyphae, giving an altered permeability of ions and peptides triggering the morphogenetic process. Nansen et al. (1988) have shown that the net-inducing capabilities of infective larvae of the cattle nematode parasite Ostertagia ostertagi and the free-living nematode $P$. redivivus were comparable.

Growing vegetative hyphae are rhythmically predisposed for peak production of nets. At $21^{\circ} \mathrm{C}$, maximum numbers of nets in $\mathrm{A}$. oligospora were formed periodically along hyphae with age differences of approximately 42 h (Lysek \& Nordbring-Hertz 1981). It has been found that $A$. oligospora produce substances that attract a wide range of nematodes (Jansson \& Nordbring-Hertz 
1980). This is in accordance with results of Balan et al. (1974) who found that the production of attractants in A. oligospora was potentiated by traps formed in the presence of nematodes.

The nets in A. oligospora are composed of hyphae that are more robust and with a cell wall often 4-5 times thicker than the vegetative hyphae (Nordbring-Hertz \& Stalhammer-Carlemalm 1978). The trapping nets are covered with a mucilagineous coat that sticks to living nematodes, and there is experimental evidence for the presence of a lectin on the net surface which binds to a carbohydrate on the nematode cuticle (Nordbring-Hertz \& Mattiasson 1979, Mattlasson et al. 1980). The adhesion mechanism has been shown to be equally effective against a range of bacteria-feeding and plantparasitic nematodes (Jansson \& NordbringHertz 1980) as well as a range of animal-parasitic nematodes (Nansen et al. 1988). Observations by Nordbring-Hertz \& Stålhammer-Carlemalm (1978) indicate that the struggling of captured nematodes trigger an increased secretion of adhesive substances between the fungal traps and the nematodes. Penetration of trapped $P$. redivivus was observed within $1 \mathrm{~h}$ by Nordbring-Hertz \& Stålhammer-Carlemalm (1978). The mechanism by which the cuticle is penetrated is not known, but it is possible that it is partly mechanic and partly enzymatic (Barron 1981). Within $45 \mathrm{~min}$. of penetration, an infective bulb is formed inside the trapped nematode (Shepherd 1955), at which time movements of the nematode ceased completely. Apparently nets in A. oligospora secrete a nematotoxin which paralyses or kills trapped nematodes (Olthof \& Estey 1963). From this bulb, which reaches a size about half the diameter of the nematode, trophic hyphae grow out and extend throughout the body of the nematode (Fig. 1). After $6 \mathrm{~h}$ the whole body of the P. redivivus was filled with hyphae (Nordbring-Hertz \& StålhammerCarlemalm 1978).

Nansen et al. (1986) compared the predacious activity of $A$. oligospora on the preparasitic stages of the cattle nematode parasite Cooperia oncophora and the free-living soil nematode $P$ redivivus. The first and second larval stages of C. oncophora and $P$. redivivus were killed rapidly; in contrast, third-stage parasite larvae wriggled in the traps for many hours. This may be because it is time-consuming for A. oligospora to penetrate the outer cuticle of the previous moult which protects both $C$. oncophora and $O$ ostertagi larvae in their third and infective stage until infection of the host takes place.

Generally, morphogenic processes are highly influenced by environmental factors. The series of experiments presented in this paper was performed to investigate the influences of temperature, concentrations of nematodes, oxygen tensions, light, and nutrient levels, on net formation in A. oligospora induced by infective larvae of the cattle nematode parasite $O$. ostertagi. The trapping capability of nets of increasing age was investigated using the free-living nematode $P$. redivivus.

\section{Materials and methods}

General experimental conditions

The fungi were grown on diluted Corn Meal Agar (Difco) (CMA 1:10) (Lysek \& Nordbring-Hertz 1981): Temperature $=20^{\circ} \mathrm{C}$; relative humidity $=90-100 \% ; \mathrm{pH}=6,5$; normal atmosphere $\left(21 \% \mathrm{O}_{2}(\mathrm{v} / \mathrm{v})\right)$; and darkness. Only deviations from these conditions are mentioned in the following descriptions of single experiments. 
Saprophytic growth rate of different species of Arthrobotrys

This experiment was performed in large Petri dishes (diam.: $8.5 \mathrm{~cm}$ ). Five Arthrobotrys species (A. oligospora (ATCC 24927), A. musiformis, A.tortor (4-182-3-INRA), A. conoides (CBS 109.52), and A. arthrobotryoides (CBS 118.54)) were inoculated in the centre of the dishes. Three Petri dishes with each species were placed at each of the following constant temperatures: $5^{\circ}, 10^{\circ}, 15^{\circ}$, $20^{\circ}, 25^{\circ}, 30^{\circ}$, and $35^{\circ} \mathrm{C}$. The radii of the colonies were measured after 3 days, and the average saprophytic growth rate of each fungal species at each temperature was calculated in $\mathrm{mm} / 3$ days.

The influence of different factors on the induction of trapping nets in Arthrobotrys oligospora

These experimentswere performed in small Petri dishes (diam.: $3.5 \mathrm{~cm}$; area: $9.6 \mathrm{~cm}^{2}$ ). The predacious fungus $A$. oligospora (ATCC 24927) was inoculated in the centre of the Petri dishes. One week later, when the fungus covered the whole surface, nets were induced by adding infective $O$. ostertagi larvae in 3 drops of non-sterile water to each culture. Infective $O$. ostertagi larvae had been kept in shallow water at $5^{\circ} \mathrm{C}$ for 1 week to 3 months. Immediately before use, the larvae were washed 3 times in tap water, using centrifugation followed by decantation of the supernatant. All larvae were living and motile when added to the fungal cultures.

After a period of some days, the number of trapping nets and the number of loops per net were determined. The number of nets were counted on 5 randomly selected areas of $3.14 \mathrm{~mm}^{2}$ on the surface of each Petri dish situated between the centre and the rim of the dishes. The number of loops per net was counted on 2 randomly selected nets in each area. The average number of nets per $\mathrm{cm}^{2}$ and the average number of loops per net could then be calculated for each treatment.

Net induction at different temperatures. Cultures of $A$. oligospora were induced by 50 infective $O$. ostertagl larvae per $\mathrm{cm}^{2}$ at each of the following constant temperatures: $5^{\circ}, 10^{\circ}, 15^{\circ}, 20^{\circ}, 25^{\circ}, 30^{\circ}$, and $35^{\circ} \mathrm{C}$. Three petri dishes were incubated at each temperature. The numbers of nets and loops were counted after 3 days of contact with the parasite larvae.

Net induction at different concentrations of parasite larvae. Cultures of A. oligospora, grown on CMA 1:10 containing $0.02 \%$ tetracycling chloride, were induced by $10,100,300,600$, and 1,000 infective $O$. ostertagi larvae per $\mathrm{cm}^{2}$. The supernatant from the last larval washing was used in control Petri dishes without larvae. Tetracycline chloride was added to the medium to suppress bacterial growth, especially in dishes with high larval concentrations, as the larvae were non-sterile. For each larval concentration, 2 Petri dishes were incubated at $20^{\circ} \mathrm{C}$ for 5 days, after which time nets and loops were counted.

Net induction at different oxygen tensions (v/v). Cultures of A. oligospora were induced by 50 infective $O$. ostertagi larvae per $\mathrm{cm}^{2}$. Three Petri dishes were placed in each of three 2.5-litre containers. In the first container $\mathrm{O}_{2}$ was replaced by $\mathrm{CO}_{2}$ by Anaerocult ${ }^{\circledR} \mathrm{A}$ (Merck), in the second there was a normal atmosphere $\left(21 \% \mathrm{O}_{2}\right)$, and in the third there was a pure $\mathrm{O}_{2}$ atmosphere. The pressure was $750-770 \mathrm{~mm} \mathrm{Hg}$. The containers were incubated at $20^{\circ} \mathrm{C}$ for 2 days, after which time the numbers of nets and loops per net were countered. During the follow- 
ing days all categories of Petri dishes were observed at normal atmosphere $\left(21 \% \mathrm{O}_{2}\right)$.

Net induction in light and darkness. Cultures of A. oligospora were induced by 50 infective $O$. ostertagi larvae per $\mathrm{cm}^{2}$, and incubated at $20^{\circ} \mathrm{C}$. Six Petri dishes were placed under constant electric light at 500 Lux, while 6 other dishes were incubated in the dark. The trial was finished 7 days later by counting nets and loops per net.

Net induction at different concentrations of corn meal in the medium. The predacious fungus A.oligospora was cultivated on agar containing an increasing amount of corn meal per litre $(0.0,0.1,0.2$, $0.4,1.0$, and $2.0 \mathrm{~g}$ corn meal $/ 1)$. The medium was a mixture of Bacto Agar (Difco) and Corn Meal Agar (Difco) with a constant amount of $15 \mathrm{~g}$ agar per litre $(1.5 \%)$ at each medium concentration. One week old $\mathrm{A}$. oligospora cultures were induced by 50 infective $O$. ostertagl larvae per $\mathrm{cm}^{2}$. Three cultures of each category were incubated at $20^{\circ} \mathrm{C}$ for 3 days, after which time the numbers of nets and loops per net were determined.

The influence of age and temperature on the activity of nets in Arthrobotrys oligospora This experiment was performed in small Petri dishes (diam.: $3.5 \mathrm{~cm}$; area: $9.6 \mathrm{~cm}^{2}$ ) on CMA 1:10 containing $0.02 \%$ tetracycline chloride. Tetracycline chloride was added to the medium to suppress bacterial growth during the long experimental period of 7 weeks. One week old cultures of A. oligospora were induced by 60 non-sterile individuals of $P$. redivivus per $\mathrm{cm}^{2}$ at $20^{\circ} \mathrm{C}$ for 2 days. At that time, nets in excess were present in each culture (approx. 600 nets per $\mathrm{cm}^{2}$ ).

The experiment started on day 2 by placing a number of these cultures at the following temperatures: $5^{\circ}, 10^{\circ}, 15^{\circ}, 20^{\circ}, 25^{\circ}, 30^{\circ}$, and $35^{\circ} \mathrm{C}$. At intervals $(1,2,4$, and 7 weeks after the start of the experiment) 3 Petri dishes from each temperature were exposed to a known number (between 40 and 70 individuals) of $P$. redivivus per $\mathrm{cm}^{2}$ for $2 \mathrm{~h}$. No new trapping nets were produced during this period. Not-trapped nematodes were isolated from the dishes by Baermannization for $16 \mathrm{~h}$ according to Jørgensen \& Madsen (1982). Control Petri dishes without A. oligospora were treated in the same way. The activity of the nets was calculated as the mean percentage of trapped $P$. redivivus in Petri dishes inoculated with the fungus, in proportion to those in control dishes.

\section{Results}

Saprophytic growth rate of different species of Arthrobotrys

As shown in Table 1, the tested Arthrobotrys species had growth rate optima at about $20^{\circ}$ or $25^{\circ} \mathrm{C}$. The fungi $A$. oligospora, $A$. musiformis, and $A$.tortor are fast-growing species. A. oligospora and $A$ tortor grow well in the interval from $15^{\circ}$ to $30^{\circ} \mathrm{C}$. A. musiformis grows well between $15^{\circ}$ and $25^{\circ} \mathrm{C}$, but no growth was observed at $30^{\circ} \mathrm{C}$. All species, except $A$. oligospora, grew slowly at $5^{\circ} \mathrm{C}$, but none of the species showed any activity at $35^{\circ} \mathrm{C}$.

The influence of different factors on the induction of trapping nets in Arthrobotrys oligospora

Net induction at different temperatures. Temperature had a significant influence on the production of trapping nets in $\mathrm{A}$. oligospora when the fungus was induced by 50 infective $O$. ostertagi larvae per $\mathrm{cm}^{2}$ (Fig. 2). 
Table 1. The saprophytic growth rate in mm/3 days of 5 different Arthrobotrys species at different temperatures.

\begin{tabular}{lrrrrrrr}
\hline \multirow{2}{*}{ Arthrobotrys species } & \multicolumn{8}{c}{ Temperature ('C) } \\
\cline { 2 - 8 } & \multicolumn{1}{c}{10} & 15 & \multicolumn{1}{c}{20} & \multicolumn{1}{c}{25} & \multicolumn{1}{c}{30} & 35 \\
\hline A oligospora & 0.0 & 1.7 & 11.7 & 19.3 & 13.0 & 6.0 & 0.0 \\
A. musiformis & 0.3 & 2.3 & 9.7 & 17.0 & 20.0 & 0.0 & 0.0 \\
A tortor & 0.3 & 0.8 & 5.3 & 13.3 & 11.3 & 11.3 & 0.0 \\
$A$ conoldes & 0.3 & 1.3 & 3.7 & 5.7 & 6.0 & 1.2 & 0.0 \\
A arthrobotryoldes & 0.3 & 0.8 & 2.3 & 5.3 & 4.0 & 0.0 & 0.0 \\
\hline
\end{tabular}

A maximum of 382 nets per $\mathrm{cm}^{2}$ was induced at $20^{\circ} \mathrm{C}$, but the fungus did not respond to larvae at $5^{\circ}, 30^{\circ}$, or $35^{\circ} \mathrm{C}$ during the experimental period of 3 days. The nets were composed of $2-4$ loops.

Net induction at different concentrations of parasite larvae. In the interval between 0 and 100 infective $O$. ostertagi larvae per $\mathrm{cm}^{2}$, increasing numbers of nets per $\mathrm{cm}^{2}$ were produced in A. oligospora with increasing numbers of larvae (Fig. 3). The supernatant from larval cultures in control Petri dishes did not induce any nets at all. But when A. oligospora was induced by more

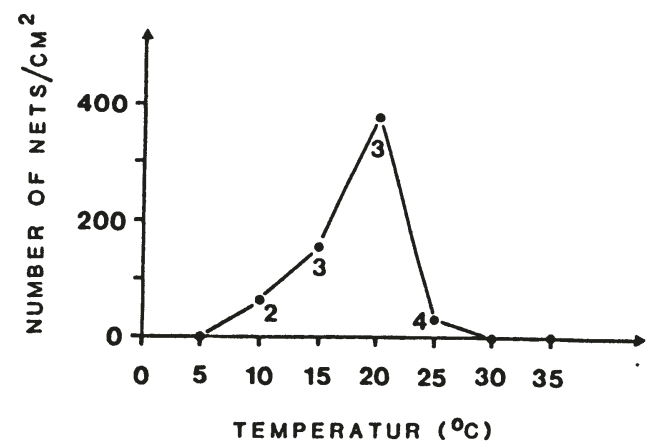

Figure 2. The average number of trapping nets $/ \mathrm{cm}^{2}$ in Arthrobotrys oligospora when the fungus was induced by 50 infective Ostertagia ostertagl larvae $/ \mathrm{cm}^{2}$ in 3 days at different temperatures. Numbers under the curve refer to the average number of loops per net. than 100 infective larvae per $\mathrm{cm}^{2}$, $1,300-1,8000$ nets per $\mathrm{cm}^{2}$ were induced. Even at a concentration of 1,000 infective larvae per $\mathrm{cm}^{2}$, all parasites were trapped, and still some nets were not occupied with larvae, as was also the case at the lower larval concentrations. At the high larval concentrations, more than one larva was trapped in many nets, which was possible as 4-8 loops were produced in each net.

Net induction at different oxygen tensions. The results presented in Table 2 show that A. oligospora does not produce nets under anaerobic conditions $\left(0 \% \mathrm{O}_{2}\right)$. In

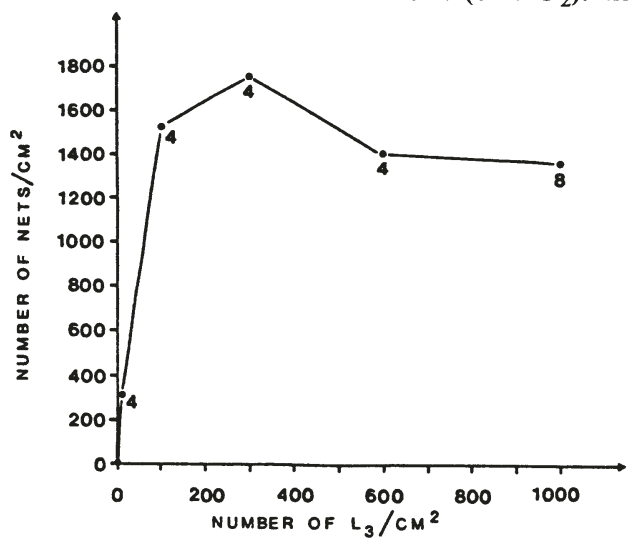

Figure 3. The average number of trapping nets $/ \mathrm{cm}^{2}$ in Arthrobotrys oligospora when the fungus was induced by increasing numbers of infective Ostertagia ostertagi larvae $\left(\mathrm{L}_{3}\right) / \mathrm{cm}^{2}$ in 5 days at $20^{\circ} \mathrm{C}$. Numbers under the curve refer to the average number of loops per net. 
Table 2. The average number of trapping nets/ $\mathrm{cm}^{2}$ in Arthrobotrys ollgospora, when the fungus was induced by 50 infective Ostertagl ostertagl larvae $/ \mathrm{cm}^{2}$ in 2 days at different oxygen tensions $(\mathrm{v} / \mathrm{v})$. In brackets are shown the average number of loops per net.

\begin{tabular}{|c|c|c|}
\hline $\begin{array}{l}\text { Anaerobic } \\
\text { atmosphere } \\
\left(0 \% \mathrm{O}_{2} \text { and }\right. \\
\left.21 \% \mathrm{CO}_{2}\right)\end{array}$ & $\begin{array}{c}\text { Normal } \\
\text { atmosphere } \\
\left(21 \% \mathrm{O}_{2} \text { and }\right. \\
\left.003 \% \mathrm{CO}_{2}\right)\end{array}$ & $\begin{array}{c}\text { Pure oxygen } \\
\text { atmosphere } \\
\left(100 \% \mathrm{O}_{2} \text { and }\right. \\
\left.0 \% \mathrm{CO}_{2}\right)\end{array}$ \\
\hline $0(0)$ & 651 (3) & 641 (3) \\
\hline
\end{tabular}

normal $\left(21 \% \mathrm{O}_{2}\right)$ and pure oxygen atmosphere $\left(100 \% \mathrm{O}_{2}\right)$ the fungus produced nets at normal rate in comparable numbers, and all larvae were trapped and killed. The infective larvae survived anaerobic conditions for 2 days and so did the fungus, as it produced nets when transferred to a normal atmosphere.

Net induction in light and darkness. As shown in Table 3, light had a negative effect on the numbers of nets induced in A. oligospora. In the present experiment only one loop was produced in each net.

Net induction at different concentrations of corn meal in the medium. The results in Fig. 4 indicate that net induction in A. oligospora was optimal at a concentration of $0.2 \mathrm{~g}$ corn meal per litre. This concentration is identical to the diluted Corn Meal Agar (CMA 1:10) which was generally

Table 3. The average number of trapping nets/ $\mathrm{cm}^{2}$ in Arthrobotrys oligospora, when the fungus was induced by 50 infective Ostertagia ostertagl larvae $/ \mathrm{cm}^{2}$ in 7 days under electric light at 500 Lux or in darkness. In brackets are shown the average number of loops per net.

\begin{tabular}{cc}
\hline Light & Darkness \\
\hline $191(1)$ & $478(1)$ \\
\hline
\end{tabular}

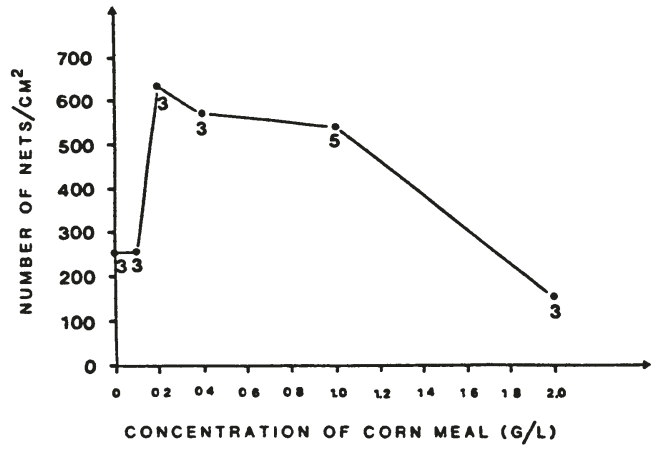

Figure 4. The average number of trapping nets $/ \mathrm{cm}^{2}$ in Arthrobotrys oligospora when the fungus was induced by 50 infective Ostertagia ostertagl larvae $/ \mathrm{cm}^{2}$ in 3 days. The growth medium contained different amounts of corn meal. Numbers under the curve refer to the average number of loops per net.

used. On increasing concentrations of corn meal the fungus produced a mycelium of increasing density. Nevertheless, A. oligospora produced significantly fewer nets per $\mathrm{cm}^{2}$ at the highest mycelial density on $2 \mathrm{~g}$ corn meal per litre than at low mycelial density on $0.2 \mathrm{~g}$ corn meal per litre.

The influence of age and temperature on the activity of nets in Arthrobotrys oligospora In Fig. 5 it appears that a proportion of the trapping nets in A. oligospora will maintain their trapping potential for more than 7 weeks when the temperature is below $25^{\circ} \mathrm{C}$. Traps kept at $30^{\circ}$ and $35^{\circ} \mathrm{C}$ lose their trapping capability after 7 and 4 weeks, respectively. But this may partly be due to dryingout of the agar medium at these high temperatures.

\section{Discussion}

As pointed out by Eren \& Pramer (1978), both growth and trap formation are prerequisites to nematode capture. Experiments have shown that conidia of the predacious 


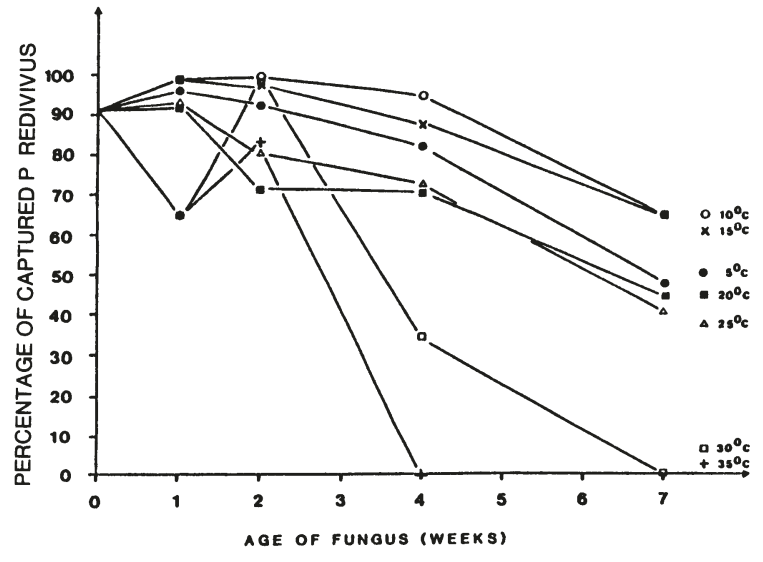

Figure 5. The effect of temperature on the average percentage of captured Panagrellus redivivus added to Arthrobotrys oligospora culture of different age.

fungus A. oligospora, when added to cattle faeces, resulted in a reduction of infective larvae og Cooperia spp. (Grønvold et al 1985) and Ostertagia ostertagi (Grønvold et al. 1988). Moreover, the trapping effect in faeces was shown to depend on the level of inoculation. This may be explained in two different ways. First, results from the present experiments have shown that $A$. oligospora has a high saprophytic growth rate in pure cultures. In competition with other microorganisms in the cow pat, saprophytic growth may be suppressed by fungistasis. In antagonistic environments germinating conidia may form traps immediately with minimal hyphal extension (Mankau 1962). In such situations it is obvious that the trapping effect depends on the inoculum level. However, in contact with other microorganisms, only a small percentage of germinating $A$. oligospora conidia quickly gave rise to trapping organs (Cooke 1964). Secondly, it is also possible that a high inoculum level is necessary for A. oligospora to grow successfully in competition with other micro- organisms, as pointed out by Cooke (1963). If this is the case, a high inoculum level will ensure that the fungus is able to colonize the faeces with a mycelium on which nets may be induced in high numbers. Above all, the present experiments have been dealing with factors influencing induction of trapping nets on a well-established A. oligospora mycelium.

Contact with nematodes was necessary for induction of trapping nets on no more than 1 week old vegetative hyphae in this strain of A. oligospora. Spontaneous trap formation was never seen under the present experimental conditions. Furthermore, non-sterile supernatants from the nematode cultures were not able to induce nets.

When induced by infective $O$. ostertagl larvae, A. oligospora had a high trapping potential. Maximum of nets was produced at $20^{\circ} \mathrm{C}$, at which temperature nets in surplus were induced at larval concentrations up to 1,000 larvae per $\mathrm{cm}^{2}$. As each loop in a net is a potential trap, the trapping capacity of A. oligospora was even higher than indicated by the number of nets, because each net normally consisted of several loops.

The present experiment indicates that trap formation in A. oligospora is an aerobic process. But it is also possible that the replacement of $\mathrm{O}_{2}$ by $\mathrm{CO}_{2}$ in the experimentally created anaerobic atmosphere had a negative effect on net induction. Nordbring-Hertz \& Odham (1980) have shown that increased $\mathrm{CO}_{2}$ in air to $5-10 \%(\mathrm{v} / \mathrm{v})$ totally inhibited trap formation. The trapping capability of A. oligospora is probably restricted to surface areas of the cow pats with high $\mathrm{O}_{2}$ and low $\mathrm{CO}_{2}$ tensions. In this part of the cow pats, infective $O$. ostertagi larvae may also be found in high concentrations (Rose 1961). On the surface of the cow pats net induction may be suppressed to a certain degree by exposure to light, as shown by the present ex- 
periment. On the other hand light, whether continuous, intermittent, or absent, has little influence on the saprophytic growth rate (Olthof \& Estey 1965).

The composition of the medium has an important influence on the saprophytic growth and the net-forming capability in A. oligospora. Nematodes alone cannot provide the sole energy for A.oligospora (Hayes \& Blackburn 1966). In their work, Hayes \& Blackburn (1966) showed that the vitamins biotine, thiamine, and p-aminobenzoic acid, stimulated saprophytic growth but had little effect on predacity. Nitrogen supplied as nitrate, nitrite, or urea supported both growth and predacity in $A$ digospora. Hayes \& Blackburn (1966) also found that a range of carbohydrates was able to support saprophytic growth in A. ollgospora. However, extensive mycelial growth was not always correlated with high predacity. On some carbohydrates $A$ oligospora produced little mycelium, but predacity was high. NordbringHertz (1973) found that on low-nutrient media phenylalanyl-valine induced trap formation in $A$ ollgospora, but the effect was greatly reduced or annulled in a nutrientrich medium or on water agar. These informations correspond with the present results where maximum numbers of nets were induced at a relatively low concentration of corn meal which supported a relatively sparse mycelium. Based on the above-mentioned results it is possible that the nutrient level in cow pats are not always optimal for net induction.

The long survival of trapping nets at high humidity and temperatures below $25^{\circ} \mathrm{C}$ is surprising, as vegetative hyphae were observed to collapse within a couple of weeks. The present results indicate that capture of infective parasite larvae in the cow pats may continue for a long time under suitable conditions. As parasite nematode larvae do not multiply, the only result of predacious activity is a reduction of the population of infective larvae. Furthermore, old nets may act as survival structures.

\section{Acknowledgements}

The author wishes to express his gratitude to Dr. Bırgit Nordbrıng-Hertz, Lund university, Sweden, and to Dr. Michèle Peloille, INRA, Monnaie, France, for providing the fungal cultures.

Ms. Annette Kørner is thanked for valuable technical assistance. The author is also indebted to Ms. Jane Røken for correcting and typing the manuscript.

The work was supported by grant No. 13-3716 from the Danısh Veterinary and Agricultural Research Council.

\section{References}

Balan J, Kriżkov́a L, Nemec P, Vollek $V$ Production of nematode-attractıng and nematicidal substances by predacious fungi. Folia Microbiol. 1974, 19, 512-519.

Barron GL Predators and parasites of microscopic anımals. In: Biology of Conidial Fungl (Cole GT, Kendrick K, eds.). Academıc Press, New York 1981, 2, 167-200.

Cooke $R C$ Ecological characteristics of nematode-trappıng Hyphomycetes I. Preliminary studies. Ann. appl. Biol. 1963, 52, 431-437.

Cooke RC Ecological characteristics of nematode-trappıng Hyphomycetes II. Germination of conıdia in soil. Ann. appl. Biol. 1964, 54, 375-379.

Eren J, Pramer $D$ Growth and activity of the nematode-trapping fungus Arthrobotrys conoldes in soll. In: Microbial Ecology (Loutit MW, Miles JAR, eds.). Springer-Verlag, Berlin 1978, 121-127.

Grønvold J, Korsholm H, Wolstrup J, Nansen P, Henriksen SvAa Laboratory experiments to evaluate the ability of Arthrobotrys oltgospora to destroy infective larvae of Cooperia species, and to investigate the effect of physical factors on the growth of the fungus. J. Helminthol. 1985, 59, 119-125. 
Grønvold J, Nansen P, Henrlksen SvAa, Thylin J, Wolstrup $J$. The capability of the predacious fungus Arthrobotrys ollgospora (Hyphomycetales) to reduce numbers of infective larvae of Ostertagla ostertagl (Trichostrongylidae) in cow pats and herbage during the grazing season in Denmark. J. Helminthol. 1988, 62, 271-280.

Hayes $W A$, Blackburn $F$ Studies on the nutrition of Arthrobotrys oligospora Fres. and $A$ robusta Dudd. II. The predaceous phase. Ann. appl. Biol. 1966, 58, 51-60.

Jansson $H-B$, Nordbring-Hertz $B$ Interactions between nematophageous fungi and plant-parasitic nematodes: Attraction, induction of trap formation and capture. Nematologica. 1980, 26, 383-389.

Jørgensen RJ, Madsen $K$. Undersøgelse af fæcesprøver for lungeormlarver. (Examination of faecal samples for lungworm larvae). Dansk VetTidsskr. 1982, 65, 517-518.

Lysek G, Nordbring-Hertz $B$ An endogenous rhythm of trap formation in the nematophagous fungus Arthrobotrys ollgospora. Planta. 1981, 152, 50-53.

Mankau $R$. Soil fungistasis and nematophagus fungi. Phytopathology 1962, 52, 611-615.

Mattlasson B, Johansson P-A, Nordbring-Hertz $B$ : Host-microorganism interaction; Studies on the molecular mechanisms behind the capture of nematodes by nematophagous fungi. Acta Chem. Scand. 1980, 34, 539-540.

Nansen P, Gronvold J, Henrıksen SvAa, Wolstrup $J$ : Predacious activity of the nematode-destroying fungus, Arthrobotrys oltgospora, on preparasitic larvae of Cooperia oncophora and on soil nematodes. Proc. Helminthol. Soc. Wash. 1986, 53, 237-243.

Nansen P, Gronvold J, Henriksen SvAa, Wolstrup $J$ : Interactions between the predacious fungus Arthrobotrys oligospora and third-stage larvae of a series of animal-parasitic nematodes. Vet. parasitol. 1988, 26, 329-337.

Nordbring-Hertz B: Peptide-induced morphogenesis in the nematode-trapping fungus Arthrobotrys ollgospora Physiol. Plant. 1973, 29, 223-233.
Nordbring-Hertz B. Nematode-induced morphogenesis in the predacious fungus Arthrobotrys oligospora. Nematologica 1977, 23, 443-451.

Nordbring-Hertz B, Brınk $C$ Qualitative characterization of some peptides inducing morphogenesis in the nematode-trapping fungus $\mathrm{Ar}$ throbotrys ollgospora Physiol. Plant. 1974, $31,59-63$.

Nordbring-Hertz B, Mattlasson B. Action of a nematode-trapping fungus shows lectin-mediated host-microorganism interaction. Nature 1979, 281, 477-479.

Nordbring-Hertz B, Odham $G$ Determination of volatıle nematode exudates and their effects on a nematode-trapping fungus. Microb. Ecol. 1980, 6, 241-251.

Nordbring-Hertz B, Stålhammer-Carlemalm M: Capture of nematodes by Arthrobotrys oligospora, an electron microscope study. Canad. J. Bot. 1978, 56, 1297-1307.

Olthof $H A$, Estey $R H$ A nematotoxin produced by the nematophagus fungus Arthrobotrys ollgospora Fresenius. Nature 1963, 196, 514 515.

Olthof $H A$, Estey $R H$. Relation of environmental factors to growth of several nematophagous Hyphomycetes Canad. J. Microb. 1965, 11, 939-946.

Pramer D, Stoll NR Nemin: a morphogenic substance causing trap formation by predaceous fungi. Science 1959, 129, 966-967.

Rose $J H$. Some observations on the free-living stages of Ostertagla ostertagl, a stomach worm of cattle. Parasitology 1961, 51, 295-307.

Shepherd AM Formation of the infection bulb in Arthrobotrys ollgospora Fresenius. Nature 1955, 175, 475.

\section{Sammendrag}

Induktion of nematod-fangende organer hos rovsvampen Arthrobotrys oligospora (Hyphomycetales) ved hjalp af infekttve larver af Ostertagia ostertagl (Trichostrongylidae)

Ved en serie laboratorie-forsøg blev indflydelsen af temperatur, koncentration af nematoder, ilttension, lys og substratstyrke målt som antallet af nematod-fangende svampe-net, der kunne induceres hos rovsvampen Arthrobotrys oligospora. Når 
rovsvampen blev induceret med infektive Ostertagla ostertagl larver fandtes en maksimal produktion af net ved $20^{\circ} \mathrm{C}$. ved denne temperatur dannede rovsvampen net $\mathrm{i}$ overskud ved koncentrationer af larver op til 1.000 larver pr. $\mathrm{cm}^{2}$. A. oligospora dannede ikke net under anaerobe forhold $\mathrm{i}$ en atmosfære indeholdende $21 \% \mathrm{CO}_{2}$ (rumfang/Rumfang), og induktionen af net blev undertrykt til en vis grad, når rovsvampen var udsat for lys. Mediets sammensætnıng havde en af- gørende indflydelse på væksten og net-dannelsen hos $A$ ollgospora, idet en maksimal produktion af net kunne induceres ved en relativ lav koncentration af maj mel, som gav anlednıng til et relativt sparsomt mycelium. En del af nettene hos $\mathrm{A}$ ollgospora bevarede deres fangst-potentiale i mere end 7 uger ved temperaturer lavere end $25^{\circ} \mathrm{C}$. Induktion af nematod-fangende organer $A$ oligospora diskuteres i relation til kontrol af infektive parasitiske nematodlarver i kokasser.

(Recelved May 20, 1988, accepted June 29, 1988)

Reprints may be requested from: Jørn Grønvold, Institute of Hygiene and Microbiology, Royal Veternary and Agricultural University, 13, Bülowsvej, DK-1870 Frederiksberg C, Denmark. 
